\title{
Climate Change Fuel Cell Program
}

\author{
Project Title \\ Premium Energy for \\ LACTEC Institute For Technology Development \\ LACTEC R\&D DPT. \\ Curitiba, State of Parana. \\ Brazil
}

Final Report

Reporting Period: April 13, 2002 to April 15, 2003

DOE AWARD NUMBER: DE-FG26-01-NT 41271

31, December 2003

Report Prepared by:

Silvio Vedovatto

Manager

Fuel Cell Division

Eduardo Browne

Director

SIECO USA Representative Office

33 Cherry Lane

Airmont, New York 10952

Tel.: 845-893-5152

SiecoUS@aol.com

SIECO S.A.

Av. Juan de Garay 437

(C1153ABC) Buenos Aires, Argentina

Tel.: (5411) 4300-9999

Fax: (5411) 4300-9998

www.sieco.com.ar 


\section{Disclaimer:}

This report was prepared as an account of work sponsored by an agency of the United States Government. Neither the United States Government nor any agency thereof, nor any of their employees, makes any warranty, express or implied, or assumes any legal liability or responsibility for the accuracy, completeness, or usefulness of any information, apparatus, product, or process disclosed, or represents that its use would not infringe privately owned rights. Reference herein to any specific commercial product, process, or service by trade name, trademark, manufacture, or otherwise does not necessarily constitute or imply its endorsement, recommendation, or favoring by the United States Government or any agency thereof. 


\section{Abstract:}

On April 2002 a 200KW Phosphoric Acid Fuel Cell (PAFC) Power Plant. was installed at LACTEC Institute For Technology Development, Research and Development facilities.

The power plant installed at LACTEC site is the second of its kind in the Southern Hemisphere. Its presence, not only contributed to the creation of a Fuel Cell Stationary Power market for Brazil and the rest of the region, but increased the knowledge about fuel cell technology, and marked the point of entry as a reference for the education of a new generation of applied scientists. On its first year the power plant has operated 8,558 hours achieving an availability factor of $97 \%$ and supplying $730.50 \mathrm{MWh}$ of premium energy.

As a second regional experience with fuel cell technology, we expect this report about LACTEC PACFC power plant performance, applications and cost-benefit evaluation will provide relevant information for future regional investments on this technology. 


\section{Table of Contents:}

Disclaimer _

Abstract

Table of Contents

Executive Summary

Introduction _- $-----------------\quad 6$

Project Schedule and Installation

Results and Discussion

Reliability Metrics _

Indices_-

Operating Hours / Availability __________- 8

Mean Time Between Forced Outages________- 9

Shutdowns Summary _-__-

Efficiency $_{-\ldots \ldots} \ldots \ldots$

Thermal Output__-_-_-_-_-_-_-_-_-_-_- 12

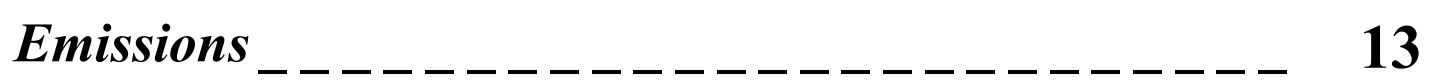

Cost Benefit Analysis _

Conclusions _

Statistics _ - - - - - - - - - - - - - - - - - 20

Information Source

Photo Gallery _

Contact \& Addresses 


\section{Executive Summary}

On April 2002 a 200KW Phosphoric Acid Fuel Cell (PAFC) Power Plant was started up at LACTEC Institute For Technology Development, Research and Development facilities.

Its presence marked the point of entry as a reference for the education of a new generation of applied scientists in Brazil measuring the impact of the Fuel cells entry into the Brazilian power market.

The project involved the acquisition of information about the fuel cell technology, performance, emissions, operational training and development of installations and maintenance procedures.

The utilization of hydrogen produced in electrolytic format to fuel the unit is one of the project objectives. This goal was not achieved because of technical causes related to the modifications required on the PAFC model PC25C and the cost involved on those modifications.

The power plant application consisted on supplying premium power to LACTEC R\&D Department. Lactec laboratory uses two power systems to get the electrical power, the commercial grid and the fuel cell power plant. After the period of evaluation and considering the power plant power capacity can match the laboratory electric peak of the demand, the fuel cell power plant is thought to become the facility main electrical power source.

From the beginning of this project the use of thermal energy was not considered to be used on the current facility due to the high cost to replace the exiting system. The construction of a new laboratory facility that allows the use of power plant thermal energy suffered several delays and at the moment there is not a date for the conclusion of the work.

During this period the power plant operated 8,558 hours reaching an availability factor of $97.23 \%$. The resulting availability factor achieved the expectations and was in accordance to manufacturer records and former experiences recorded by DoD for the same power plant model.

Six shutdowns were registered, three of them were scheduled outages and three were forced outages. Regarding the forced outages, one was due to a problem with fuel cell brakes and the remaining two forced outages were the result of a failure of the three port modulating ball valve TCV400/480.

The resulting MTBFO of 2,853 hours exceed the manufacturer specifications and not only demonstrated the system reliability but achieved the project expectations.

To generate $730 \mathrm{MWhrs}$ the power plant consumed 254,530.80 $\mathrm{m} 3(8,736,988.31 \mathrm{cf})$ of natural gas. Reaching to an average electrical efficiency of $28 \%$ at gas LHV and $26 \%$ at gas HHV. Compared with recorded experiences with same units it is a low result, showing the drop on the electrical efficiency at an AC power demand under the $30 \%$ of the unit capacity. In despite of the efficiency average result, it is important to remark that high efficiency values, $37 \%$ at gas LHV ( $35 \%$ at gas $\mathrm{HHV}$ ), have been achieved demanding only the $50 \%$ of the power plant capacity. These figures exceed the performance recorded with other devices like gas turbines or diesel generators that can reach up to $30 \%$ or $35 \%$ of efficiency at its maximum capacity factor.

As expected no harmful emissions of NOx, SOx were detected, demonstrating the fact that fuel cell technology contributes to the overall benefit of the environment.

In terms of the cost benefit analysis the power plant is still an expensive alternative when compared with traditional power generation. According to the project demands the resulting cost for $\mathrm{kWh}$ generated, including amortization and maintenance costs, was USD $0.24084 \mathrm{kWh}$ (natural gas HHV), versus to USD $0.04345 \mathrm{kWh}$ conventional rate for $13.8 \mathrm{kV}$ medium voltage, USD $0.06779 \mathrm{kWh}$ residential low voltage rate and USD $0.06340 \mathrm{kWh}$ commercial and industrial low voltage rate. The main factors that affect results are application demand (electrical and thermal demand); the high cost of natural gas compared with conventional electric rates and finally the power plant acquisition cost.

The main project conclusion is that fuel cell technology demonstrated to be a reliable option for the vision of distributed power generation as an important alternative for non-polluting power generation.

The achievement of this project contributed to the regional evaluation of fuel cell technology, providing technical and commercial know how that will be applicable and very valuable when considering further regional projects. 


\section{Introduction}

The Global demand for power has created a large need to develop alternative sources of energy that will become pollution free energy sources. In the case of South America and specifically Brazil, climate changes have seriously affected the environment and the supply of power to meet the growing demand. As these economies become part of the global mainstream, clean energy alternatives can be addressed by the use of Stationary Power Fuel Cells.

Sieco S.A. (Sieco) became involved with United Technologies Fuel Cell, Inc. (former International Fuel Cells, Inc.) in 1997 and have been promoting and marketing the PC25 Power Plant based on Phosphoric Acid Fuel Cell Technology in the South America region.

From the beginning, Sieco has focused on providing Premium Power Solutions to the region and on March 2001 was able to successfully execute on its efforts by bringing the first three Fuel Cell Power Plants into Brazil, the first in the South American territory.

LACTEC is a renowned R\&D facility a Not-For-Profit Organization created to offer technological knowhow and services to support the State of Parana, Copel Power Utility, the University of Parana and the Industrial association of Parana.

During the first operational year, project objectives were focused on the acquisition of information about the fuel cell technology, performance, emissions, operational training and development of installations and maintenance procedures.

The utilization of hydrogen produced in electrolytic format to fuel the unit is one of the project objectives.

The Power plant will operate as Grid independent/Grid connected.

\section{Project Schedule and Installation}

The project implementation began with the purchase of the unit on March 12, 2001. The purchased involved a $200 \mathrm{~kW}$ Phosphoric Acid Fuel Cell (PAFC) model PC25C manufactured by United Technologies Fuel Cell (former IFC), capable to operate independent of the utility grid. The power plant was required with a low grade heat recovery heat exchanger and a single walled heat recovery heat exchanger.

The power plant electrical configuration was according to U.S. market standards for that reason it was necessary to procure the addition of two transformers to meet the power plant input / output requirements by the utility grid. Even though it was not required as an additional security measure, a reverse osmosis system to treat water inlet was included.

The unit was placed outdoors, adjacent to the Lactec R\&D Laboratory, it was conceived to operate with natural gas, 24 hours a day, 365 days per year (except for scheduled maintenance) and its main application is to provide Premium Power to the laboratory.

The technical training at the manufacturer's facility in the USA was conducted on April 2001. Site engineering was concluded on August 2001. The Fuel Cell Power Plant was delivered to the site on June 26, 2001. Permits and site preparation were originally scheduled to be concluded on September, 2001, but the project suffered several deviations because of delays during the construction work. The site preparation was concluded on March 2002. The unit installation began on March 2002 and system first start-up took place on April $13^{\text {th }}, 2002$ reaching the maximum capacity of $200 \mathrm{~kW}$ on the same date. 


\section{Results and Discussion}

\section{Reliability Metrics}

The performance indices available at Gas Technology Institute (GTI) in Des Plaines, Illinois (http://www.gri.org/pub/solutions/dg/rel_metrics.html), were selected to measure power plant reliability.

Tables and graphs showing different reliability categories for a given period of time, applied reliability indices, their definitions and results follow:

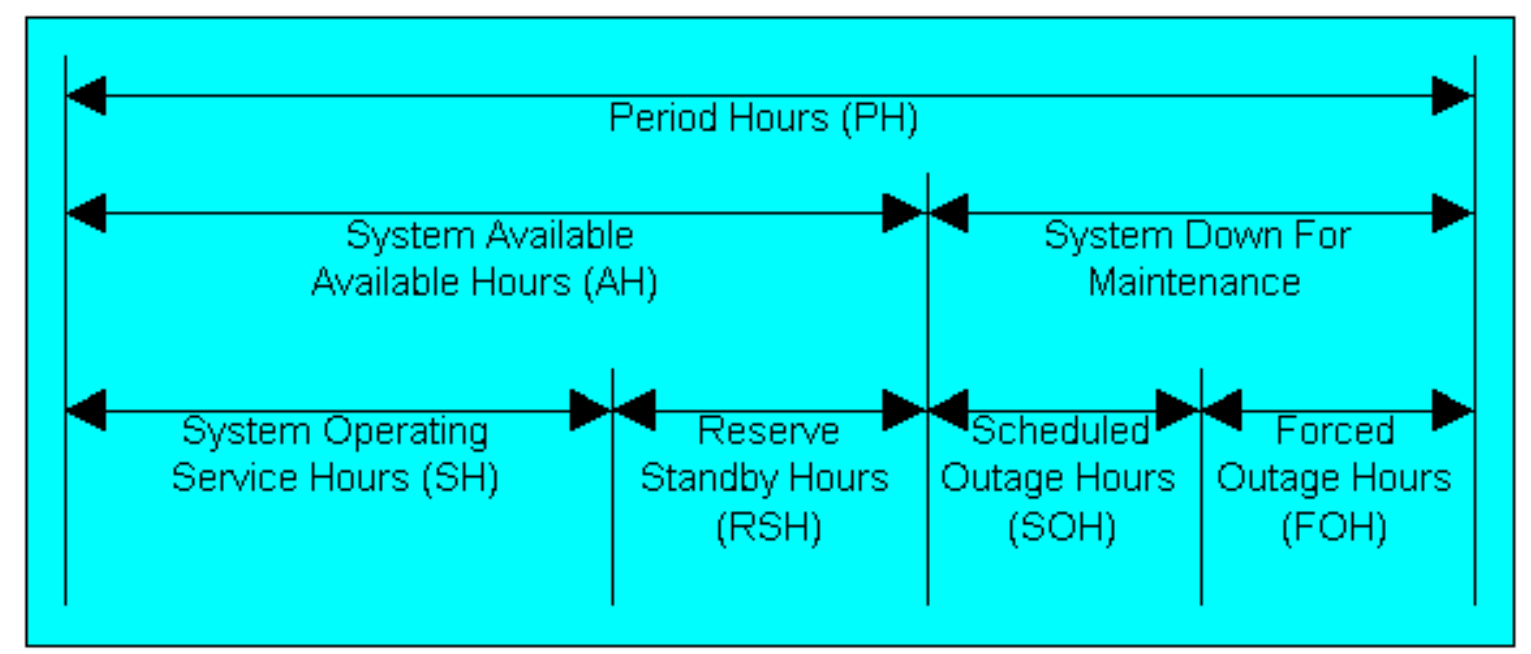

\begin{tabular}{|l|c|r|}
\hline \multicolumn{1}{|c|}{ Data } & Code & \multicolumn{1}{c|}{ Result } \\
\hline $\begin{array}{l}\text { Period of Hours } \\
\text { Period April 13-2002 I April 13-2003 }\end{array}$ & $\mathrm{PH}$ & 8802 Hours \\
\hline System Available - Available Hours & $\mathrm{AH}$ & 8558 Hours \\
\hline System Down for Maintenance & $\mathrm{SD}$ & 244 Hours \\
\hline System Operating Service Hours & $\mathrm{SH}$ & 8558 Hours \\
\hline Reserve Standby Hours & $\mathrm{RSH}$ & 0 Hours \\
\hline Planned Outages & $\mathrm{PO}$ & 3 Event \\
\hline Scheduled Outage Hours & $\mathrm{SOH}$ & 61 Hours \\
\hline Forced Outage & $\mathrm{FO}$ & 3 Events \\
\hline Forced Outage Hours & FOH & 183 Hours \\
\hline
\end{tabular}




\section{Indices:}

\begin{tabular}{|c|c|c|}
\hline Indices: & Formula & Result \\
\hline $\begin{array}{l}\text { Period of Demand (POD) } \\
\text { Measures the time the unit was planned } \\
\text { to operate }\end{array}$ & $\mathrm{POD}=\mathrm{PH}-\mathrm{RSH}-\mathrm{SOH}$ & 8741 Hours \\
\hline $\begin{array}{l}\text { Availability Factor (AF \%) } \\
\text { Measures, on a percent basis, the unit's } \\
\text { "could run" capability. Impacted by } \\
\text { planned and unplanned maintenance }\end{array}$ & $\mathrm{AF}=(\mathrm{PH}-\mathrm{SOH}-\mathrm{FOH}) \times 100 / \mathrm{PH}$ & $97.23 \%$ \\
\hline $\begin{array}{l}\text { Forced Outage Rate (FOR \%) } \\
\text { Measures portion of downtime due to } \\
\text { unplanned factors }\end{array}$ & $\mathrm{FOR}=\mathrm{FOH} \times 100 / \mathrm{SH}-\mathrm{FOH}$ & $2.19 \%$ \\
\hline $\begin{array}{l}\text { Scheduled Outage Factor (SOF \%) } \\
\text { Measures percent of time set aside for } \\
\text { planned maintenance }\end{array}$ & $\mathrm{SOF}=\mathrm{SOH} \times 100 / \mathrm{PH}$ & $0.69 \%$ \\
\hline $\begin{array}{l}\text { Service Factor (SF \%) } \\
\text { Percent of total period hours the unit is on- } \\
\text { line - varies due to site-related or } \\
\text { economic factors }\end{array}$ & $\mathrm{SF}=\mathrm{SH} \times 100 / \mathrm{PH}$ & $97.23 \%$ \\
\hline $\begin{array}{l}\text { Mean Time Between Forced Outages } \\
\text { (MTBFO) } \\
\text { Measures the nominal time between } \\
\text { unscheduled forced outages }\end{array}$ & MTBFO = SH / FO & 2853 Hours \\
\hline $\begin{array}{l}\text { Mean Down Time (MDT) } \\
\text { Measures the nominal duration the unit is } \\
\text { down during maintenance events }\end{array}$ & $\mathrm{MDT}=\mathrm{SOH}+\mathrm{FOH} / \mathrm{FO}+\mathrm{PO}$ & 41 Hours \\
\hline
\end{tabular}

\section{Operating Hours / Availability:}

Until April 2003, Lactec power plant logged 8,558 operating hours, reaching an availability factor of $97.23 \%$ during the total period of time demanded (calendar time).

On November 2001 DOD published their experience with a fleet of 30 power plants generators, comparing reported availability rate for the PC25C model (87\%), Lactec fuel cell availability factor not only achieved the expectations but also proved high system availability. 


\section{Availability Chart:}

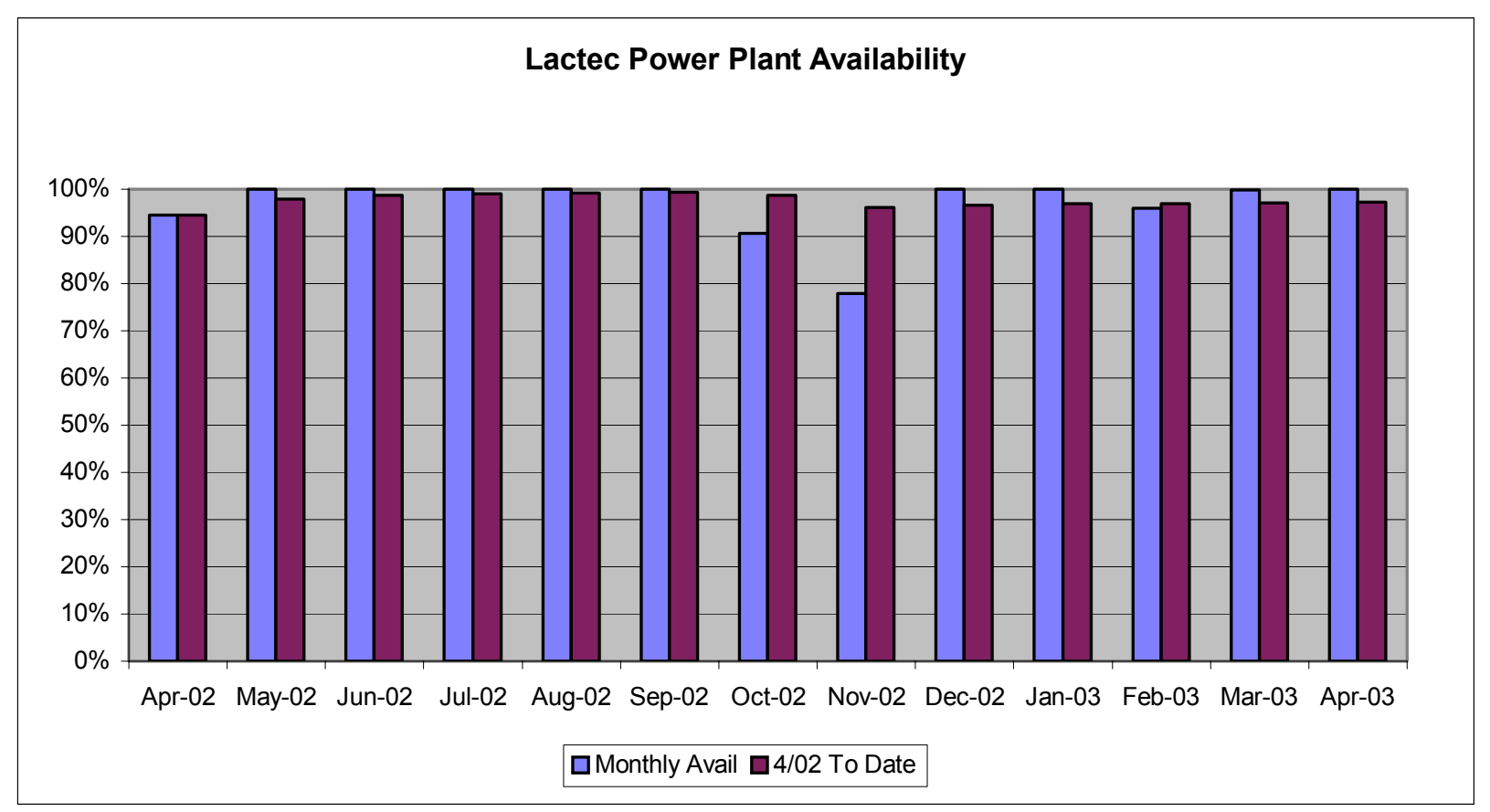

\section{Mean Time Between Forced Outages:}

During the analyzed period Lactec power plant registered six shutdowns. Three of them were a result of scheduled maintenance activities and three were forced outages. One of the forced outages was due to a problem with fuel cell brakes and the remaining two were the result of a failure of the three port modulating ball valve TCV400/4.

The resulting MTBFO of 2,853 hours exceeded manufacturer 2,500 hours records or DOD reported historical experience for the same model of 1,766 hours. The experience with the fuel cell power plant installed at Lactec not only demonstrated the system reliability but also exceeded former regional experience duplicating the registered MTBFO (1,200 hrs.).

Considering that on the former regional experience the low MTBFO was due many human mistakes when operating the power plant, the present results show also a maturity on the technical knowledge acquired by the technicians and professionals involved on the project, achieving as well one of the project main goals.

Following there is a chart with a summary of scheduled and forced outages. 
Shutdowns Summary:

\begin{tabular}{|c|c|c|c|c|}
\hline Event / Description & Date/Month/Yr & Load Time & Run Hours & $\begin{array}{l}\text { System Down } \\
\text { Hours }\end{array}$ \\
\hline First Start Up \# 9258 & $\begin{array}{c}4 / 12 / 2002 \\
4: 16\end{array}$ & 420 & & \\
\hline $\begin{array}{l}\text { Shutdown } \\
\text { Brakes failure }\end{array}$ & $\begin{array}{c}/ 22 / 2002 \\
12: 17\end{array}$ & 669 & 249 & \\
\hline Restart & $\begin{array}{c}4 / 23 / 2002 \\
13: 17\end{array}$ & 669 & & 25 \\
\hline $\begin{array}{l}\text { Shutdown } \\
\text { Scheduled shutdown for maintenance } \\
\text { purposes }\end{array}$ & $\begin{array}{c}10 / 3 / 2002 \\
9: 45\end{array}$ & 4574 & 3905 & \\
\hline Restart & $\begin{array}{c}10 / 4 / 2002 \\
18: 45\end{array}$ & 4574 & & 33 \\
\hline $\begin{array}{l}\text { Shutdown } \\
\text { Failure of the three port modulating ball } \\
\text { valve TCV400/480 }\end{array}$ & $\begin{array}{c}11 / 14 / 2002 \\
14: 32\end{array}$ & 5557 & 983 & \\
\hline Restart & $\begin{array}{c}11 / 20 / 2002 \\
10: 48\end{array}$ & 5557 & & 140 \\
\hline $\begin{array}{l}\text { Shutdown } \\
\text { Failure of the three port modulating ball } \\
\text { valve TCV400/480 }\end{array}$ & $\begin{array}{c}11 / 20 / 2002 \\
15: 48\end{array}$ & 5562 & 5 & \\
\hline Restart & $\begin{array}{c}11 / 21 / 2002 \\
9: 51\end{array}$ & 5562 & & 18 \\
\hline $\begin{array}{l}\text { Shutdown } \\
\text { Scheduled shutdown for maintenance } \\
\text { purposes }\end{array}$ & $\begin{array}{c}2 / 11 / 2003 \\
7: 23\end{array}$ & 7527 & 1965 & \\
\hline Restart & $\begin{array}{c}3 / 12 / 2003 \\
10: 31\end{array}$ & 7527 & & 27 \\
\hline $\begin{array}{l}\text { Shutdown } \\
\text { Scheduled shutdown for maintenance } \\
\text { purposes }\end{array}$ & $\begin{array}{c}3 / 18 / 2003 \\
9: 00\end{array}$ & 8342 & 815 & \\
\hline Restart & $\begin{array}{c}3 / 18 / 2003 \\
9: 40\end{array}$ & 8342 & & 1 \\
\hline Last Measuring & $\begin{array}{c}/ 13 / 2003 \\
22: 02\end{array}$ & 8978 & 636 & \\
\hline
\end{tabular}




\section{Efficiency}

Information published by the natural gas vendor, "Compagas", was included to estimate the system efficiency. Following are the listed Compagas heat value for natural gas and units conversion.

Natural Gas LHV $=8650 \mathrm{kcal} / \mathrm{m} 3=10,06 \mathrm{kWh} / \mathrm{m} 3=34326 \mathrm{Btu} / \mathrm{m} 3=972 \mathrm{Btu} / \mathrm{cf}$.

Natural Gas HHV $=9400 \mathrm{kcal} / \mathrm{m} 3=10,93 \mathrm{kWh} / \mathrm{m} 3=37292 \mathrm{Btu} / \mathrm{m} 3=1056 \mathrm{Btu} / \mathrm{cf}$.

During period Lactec power plant operated at an average AC Output of $85 \mathrm{Kw}$ ( $43 \%$ of its total capacity) presenting an average electrical conversion efficiency at natural gas LHV of $28 \%$ with a maximum efficiency record of $37.9 \%$ at a $50 \%$ of fuel cell capacity (Monthly average AC demand $99 \mathrm{kw}$ ) and a minimum of $14 \%$ at an average $\mathrm{AC}$ demand of $33 \mathrm{kw}$ ( $17 \%$ of power plant capacity). Considering the power plant AC output demand and the gas consuming, it is possible to prove the linear relationship up to the $50 \%$ of power plant capacity $(100 \mathrm{kw})$, which complies with manufacturer parameters that indicates a $57 \mathrm{mts} 3 / \mathrm{hrs}$ at maximum capacity and $30 \mathrm{mts} 3 / \mathrm{hrs}$ at $50 \%$ capacity $(100 \mathrm{kw})$. Below this point that relationship is no longer valid, affecting the unit efficiency as well. The reason for the increase on the gas consume and resulting drop of the efficiency, is because of the gas consumed at the power plant burners just to keep the operational high temperature required at the power plant reformer. At natural gas HHV, the full period average electrical conversion efficiency dropped to $26 \%$.

Average electrical conversion efficiency for other gas engines like turbines or diesel generators ranges between $25 \%$ to $30 \%$. When comparing these figures, it is demonstrated the power plant higher electrical conversion efficiency with the additional benefit that the power plant does not burn consumed fuel therefore, reducing polluting emissions.

The next step to achieve involves the stabilization of the power plant AC demand above the $50 \%$ of its capacity and to reach an average electrical efficiency of $35 \%$ at natural gas LHV.

Thermal efficiency is considered the ratio between heat recovered versus consumed natural gas heat content. The standard power plant model PC $25 \mathrm{C}$ is provided with a low grade heat exchanger capable to provide $750.000 \mathrm{Btu} / \mathrm{h}-220 \mathrm{Kw} / \mathrm{h} \mathrm{t}$ at $200 \mathrm{kw} / \mathrm{h}$ e power rate. The heat available main utilization consist on supplying hot water to the associated site. Lactec R\&D laboratory already counted with a system capable to provide hot water and because of the high cost of its replacement this application was not considered at the inception of this project. The construction of a new laboratory facility will allow the utilization of this power plant feature improving not only system total efficiency, but the economical equation. At the time of the present report the laboratory construction have not been concluded for that reason the utilization of the power plant thermal capacity is still goal to achieve.

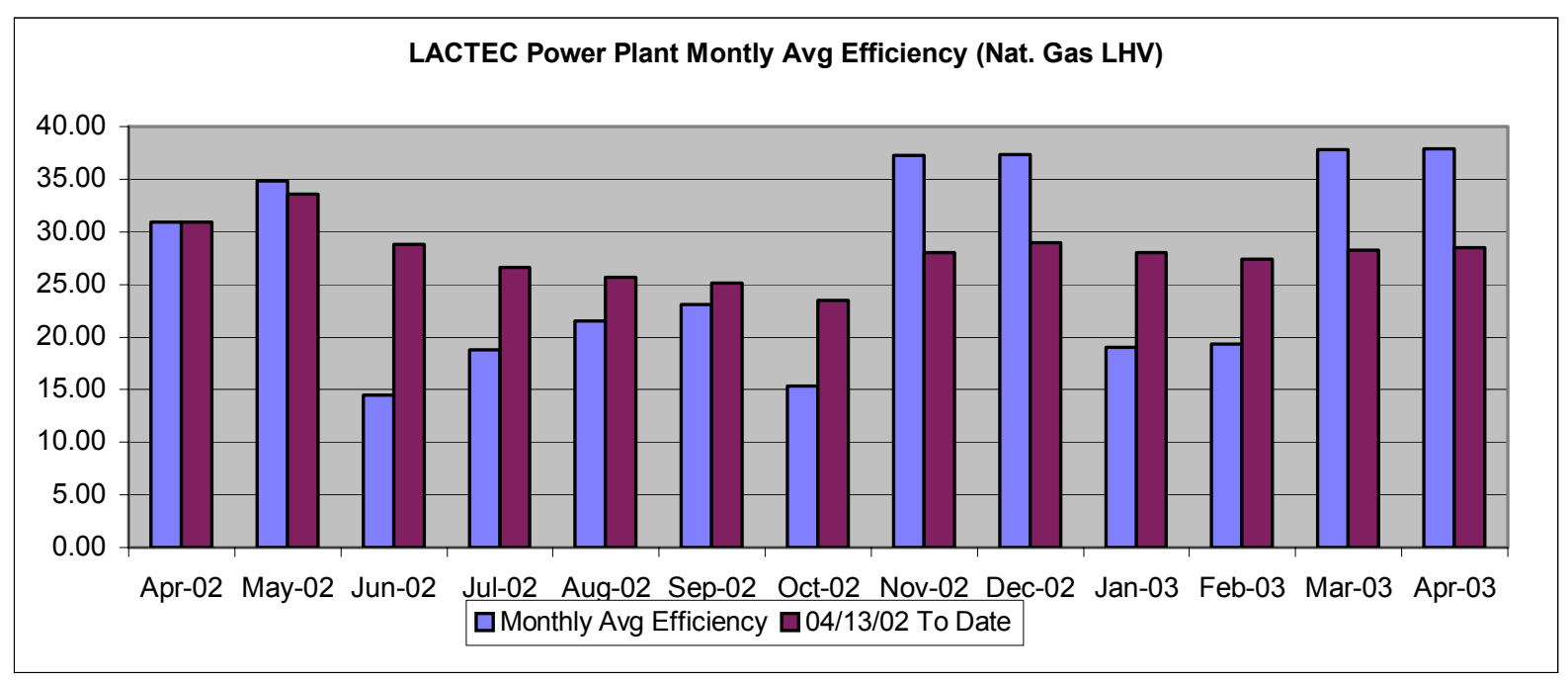




\section{Thermal Output}

The thermal output considered as the available heat rate, independent of thermal consumption, has relationship to the power plant AC Output Voltage. At a maximum rated power of $200 \mathrm{~kW}$ the power plant model PC25C is able to supply $750.000 \mathrm{Btu} / \mathrm{h}(220 \mathrm{~kW})$.

According to the manufacturer records from $200 \mathrm{~kW}$ to $100 \mathrm{~kW}$ AC Output, available heat rate drops $3 \%$ per 5\% AC Output reduction. Therefore the following chart shows available heat in $\mathrm{kW}$ according to Lactec power plant monthly AC output average.

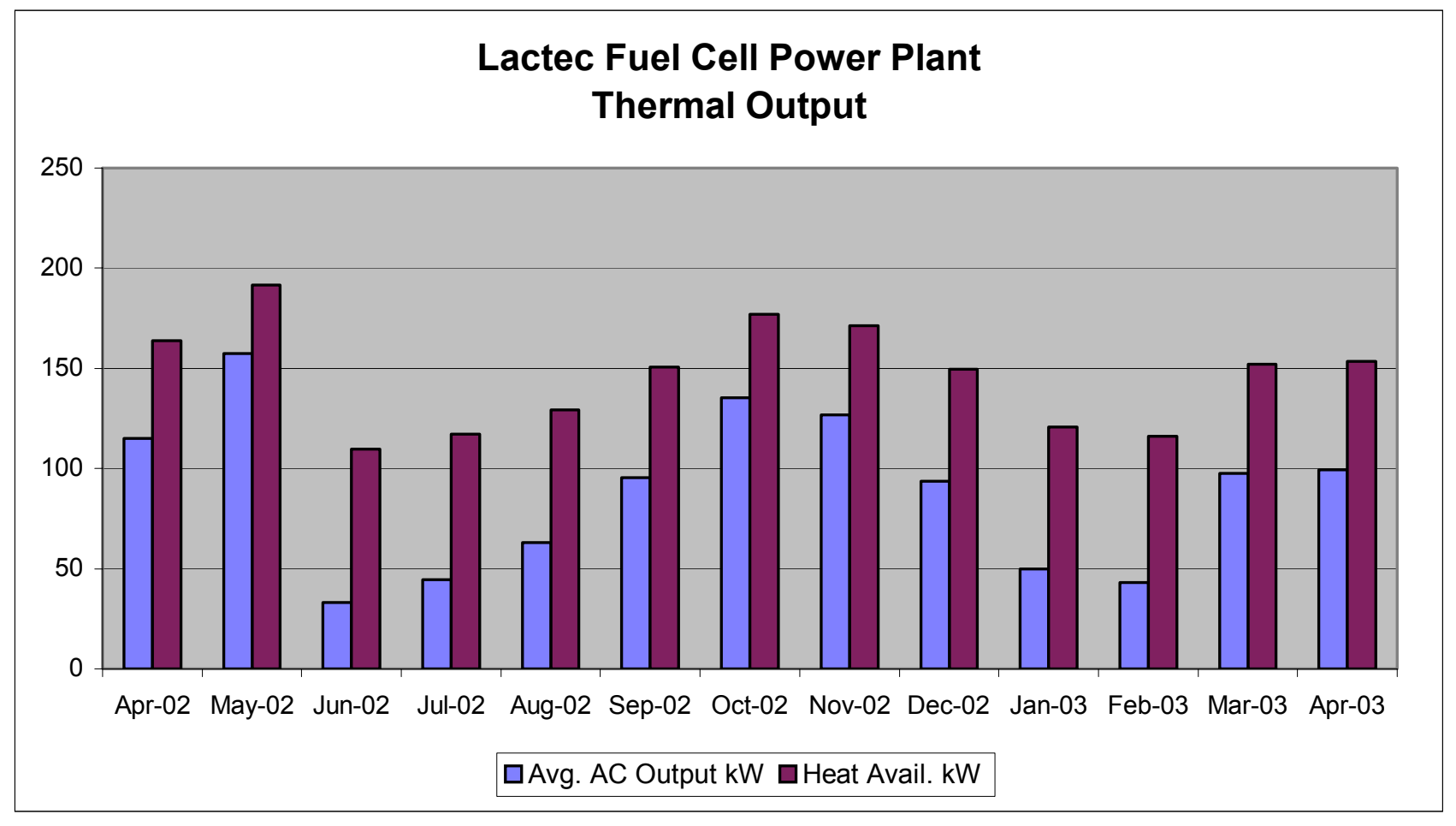




\section{Emissions}

The following chart shows Lactec Power Plant emissions:
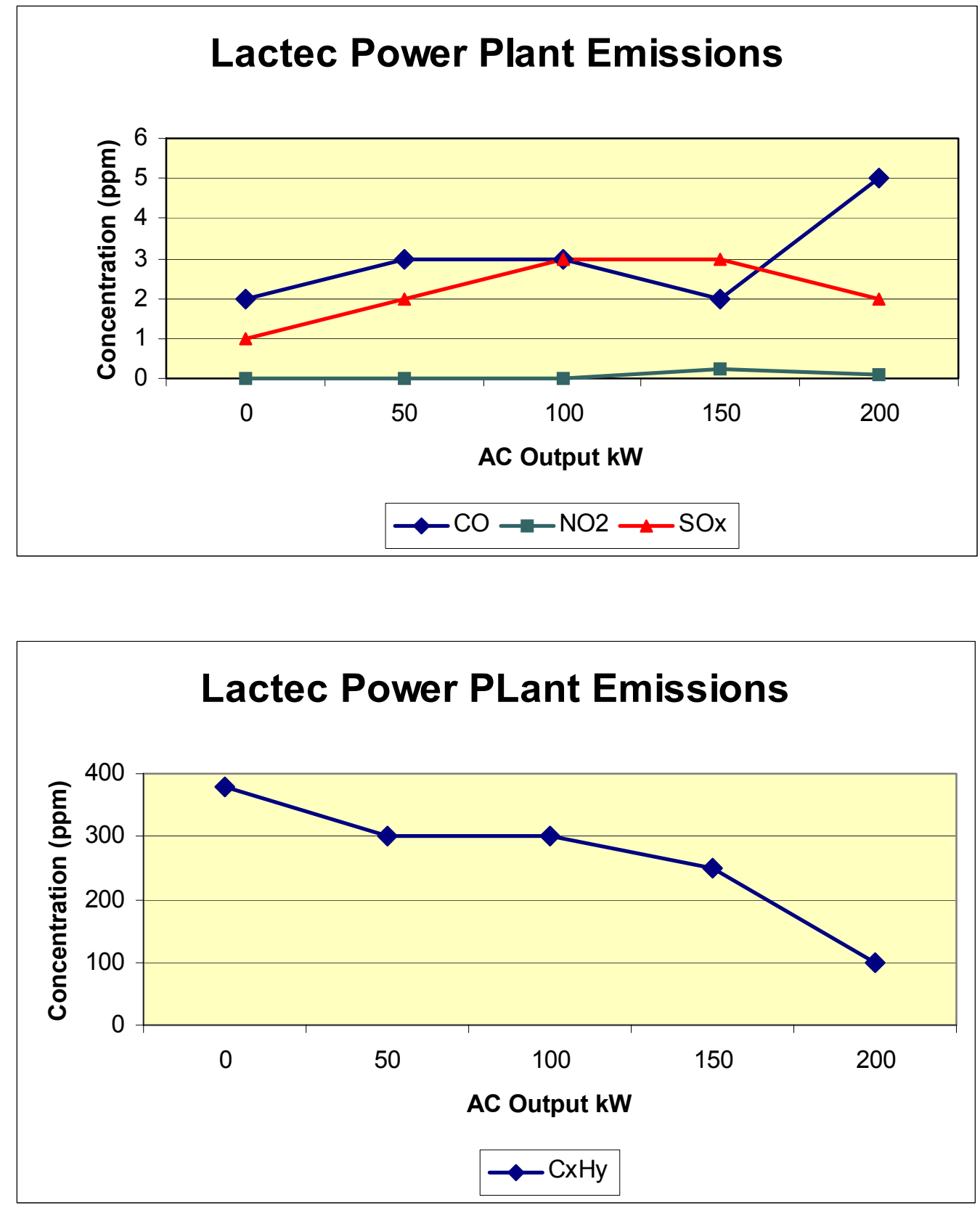

As expected no harmful emissions were generated, confirming the use of fuel cell technology as a pollution free source of energy. 


\section{Cost Benefit Analysis}

\section{Currency Exchange:}

During the analyzed period the Brazilian currency Real (R\$) has suffered a continuos depreciation compared with the USA Dollar (USD). Considering the currency exchange monthly fluctuation (April 2002 USD $1=\mathrm{R} \$ 2,28 /$ October $2002 \mathrm{U} \$ \mathrm{D} 1=\mathrm{R} \$ 3.77 /$ April 2003 USD $1=\mathrm{R} \$ 3,09$ ) a value of USD $1=\mathrm{R} \$ 3,15$ was used for the project analysis.

\section{Investment:}

The following chart shows investment forecasted at the beginning of the project versus its result at the end of it.

Investment as Planned on March 2001

\begin{tabular}{clcc}
\hline Item & \multicolumn{1}{c}{ Description } & Cost & Percent \\
\hline \hline 1 & Fuel Cell \& Miscellaneous & USD 840,000.00 & $86 \%$ \\
\hline 2 & Installation Cost & USD 40,000.00 & $4 \%$ \\
\hline 3 & First Year Fuel & USD 80,000.00 & $8 \%$ \\
\hline 4 & First Year Maintenance & USD 20,000.00 & $2 \%$ \\
\hline 5 & Total Planned Cost & USD 980,000.00 & $\mathbf{1 0 0 \%}$ \\
\hline \hline
\end{tabular}

\begin{tabular}{llcc}
\hline & Founding Source & Amount & Percent \\
\hline \hline 6 & Sieco S.A. & USD 980,000.00 & $100 \%$ \\
\hline 7 & - & - & - \\
\hline \hline 8 & Total Funding & USD 980,000.00 & $\mathbf{1 0 0 \%}$ \\
\hline \hline
\end{tabular}

\section{Investment as is, on April 2003}

\begin{tabular}{llcc}
\hline Item & \multicolumn{1}{c}{ Description } & Cost & Percent \\
\hline \hline 1 & Fuel Cell \& Miscellaneous & USD 862,650.00 & $85 \%$ \\
\hline 2 & Installation Cost & USD 68,529.90 & $7 \%$ \\
\hline 3 & First Year Fuel & USD 60,245.96 & $6 \%$ \\
\hline 4 & First Year Maintenance & USD 22,570.41 & $2 \%$ \\
\hline 6 & Total Cost & USD 1,013,996.27 & $100 \%$ \\
\hline \hline & & & \\
\hline & Founding Source & Amount & Percent \\
\hline \hline 7 & Sieco S.A. & USD 813,996.27 & $80 \%$ \\
\hline 8 & DOE & USD 200,000.00 & $20 \%$ \\
\hline \hline 9 & Total Funding & USD 1,013,996.27 & $100 \%$ \\
\hline \hline
\end{tabular}

\section{Economical Analysis:}

To evaluate the project economical results for the period, the capital amortization, power plant maintenance cost and natural gas consumption cost during the period compared to the cost of displaced natural gas and displaced electrical energy obtained from the cogeneration process was considered.

Second the Electrical Energy cost was compared, as a by-product of the power plant cogeneration process, versus available Electrical Energy rates into the State of Parana. The analysis determines the power plant requirements to be considered as a viable generation source.

\section{1-Capital Amortization:}

The power plant cost, plus installation cost and an amortization period of ten years was considered.

Capital Amortization $=\underline{\text { Power Plant Cost }+ \text { Installation Cost }}=\underline{\text { USD 862,650.00 }+ \text { USD 68,529.90 }}=$ USD 93,117.99 Amortizing Period

\section{2-First Year Maintenance Cost:}

It was equal to USD $22,570.41$ 


\section{3-Cost of Consumed Natural Gas:}

Compagas, is the company that supplies of natural gas to Lactec power plant. The following is the listed Compagas Rate Chart and the resulting natural gas rate during the period for Lactec Power Plant.

\begin{tabular}{|c|c|c|c|}
\hline Vol. M3 / day & $\begin{array}{c}\text { Gas Rate } \\
\text { R\$ }\end{array}$ & $\begin{array}{c}\text { Gas Cost With } \\
\text { Discount (10\%) R\$ }\end{array}$ & $\begin{array}{c}\text { Gast With } \\
\text { Discount (10\%) } \\
\text { USD } \mathbf{R} \text { ( } 3,155 \\
\text { USD }\end{array}$ \\
\hline 0 to 500 & 0.871444 & 0.7842996 & 0.248589 \\
\hline 501 to 1000 & 0.732222 & 0.6589998 & 0.208875 \\
\hline 1001 to 2000 & 0.627555 & 0.5647995 & 0.179017 \\
\hline 2001 to 4000 & 0.575333 & 0.5177997 & 0.164120 \\
\hline
\end{tabular}

Prices according to COMPAGAS Rates (http://www.compagas.com.br/port/tabelaprecos.asp?tipo=1)

The resulting rate is obtained prorating daily natural gas consumed in $\mathrm{m} 3$ per each rate parameter.

Example: Power plant at rated power $200 \mathrm{kw}$ consuming $57 \mathrm{~m} 3 / \mathrm{h}$ of natural gas.

Consume: $57 \mathrm{~m} 3 / \mathrm{h} * 24=1.368 \mathrm{~m} 3 /$ day

Rate $=\underline{(500 \mathrm{~m} 3 * \text { USD } 0.248589)+(500 \mathrm{~m} 3 * \text { USD } 0,208875)+(368 \mathrm{~m} 3 * \text { USD } 0,178017)})=$ USD $0.215360 \mathrm{~m} 3$

$$
1,368 \mathrm{~m} 3
$$

During this period the Lactec Power Plant consumed 8,988,671.1 cubic feet of natural gas, equal to $254,530.9 \mathrm{~m} 3$ at an average rate of USD $0.2367 \mathrm{~m} 3$. Resulting on a total cost of USD 60,245.96

Lactec Power Plant Consumed Natural Gas Cost Chart:

\begin{tabular}{|c|c|c|c|c|}
\hline Fuel Cell Avg. Gas Rate & Fuel Cell Avg. Gas Rate & Fuel Cell Nat. Gas Consume & \multicolumn{2}{|c|}{ Fuel Cell Nat. Gas Cost } \\
\hline $\mathrm{R} \$ 0.74677 \mathrm{~m} 3$ & USD $0.236694 \mathrm{~m} 3$ & $254,530.85 \mathrm{~m} 3$ (LHV) & USD & $60,245.96$ \\
\hline $\mathrm{R} \$ 0.74677 \mathrm{~m} 3$ & USD $0.236694 \mathrm{~m} 3$ & $254,530.85 \mathrm{~m} 3$ (HHV) & USD & $60,245.96$ \\
\hline $\mathrm{R} \$ 0.02176 \mathrm{Kbtu} / \mathrm{h}$ (LHV) & USD 0.006896Kbtu/h (LHV) & 8,736,988.31 Kbtu/h (LHV) & USD & \\
\hline $\mathrm{R} \$ 0.02002 \mathrm{Kbtu} / \mathrm{h}(\mathrm{HHV})$ & USD $0.006347 \mathrm{Kbtu} / \mathrm{h}$ (HHV) & 9,492,036.68Kbtu/h (HHV) & USD & $60,245.96$ \\
\hline $\mathrm{R} \$ 0.07423 \mathrm{kWh}$ (LHV) & USD 0.023528kWh (LHV) & $2,560,558.77 \mathrm{kWh}$ (LHV) & USD & $60,245.96$ \\
\hline $\mathrm{R} \$ 0.06833 \mathrm{kWh}(\mathrm{HHV})$ & USD $0.021657 \mathrm{kWh}(\mathrm{HHV})$ & $2,781,841.63 \mathrm{kWh}$ (HHV) & USD & $60,245.96$ \\
\hline
\end{tabular}

\section{4-Cost of Displaced Natural Gas due to Thermal Utilization:}

Since there was no thermal utilization, no saving as displaced natural gas cost was registered during the period. 
$\underline{5-C o s t ~ o f ~ D i s p l a c e d ~ E l e c t r i c a l ~ E n e r g y ~ d u e ~ t o ~ f u e l ~ c e l l ~ g e n e r a t i o n: ~}$

In Brazil, the National Electrical Energy Agency (ANEEL) regulates and determines the electrical energy rates. For this analyzed period ANEEL had enforced two regulations that determined the electrical energy rate. Following are the listed rate charts used.

\begin{tabular}{|l|r|r|r|r|}
\hline \multirow{2}{*}{$\begin{array}{c}\text { Conventional } \\
\text { Rate }\end{array}$} & \multicolumn{2}{|c|}{ ANEEL 226 July 2001 to June 2002 } & \multicolumn{2}{l|}{ ANEEL 226 July 2001 to June 2002 } \\
\cline { 2 - 5 } & Demand $\mathrm{R} \$ \mathrm{~kW}$ & Consume R\$/kWh & Demand USD/kW & Consume USD/kWh \\
\hline $\mathrm{A} 4$ (13,8V Medium Volt.) & $\mathrm{R} \$ 6.960$ & $\mathrm{R} \$ 0.10195$ & USD 2.2060 & USD 0.0323 \\
\hline B1 (Residential Low Volt) & & $\mathrm{R} \$ 0.19781$ & & USD 0.0627 \\
\hline B3 (Comm. \& Ind. Low Volt.) & & $\mathrm{R} \$ 0.18500$ & & USD 0.0586 \\
\hline
\end{tabular}

\begin{tabular}{|l|r|r|r|r|}
\hline \multirow{2}{*}{$\begin{array}{c}\text { Conventional } \\
\text { Rate }\end{array}$} & \multicolumn{2}{|c|}{ ANEEL 336 July 202 to Date } & \multicolumn{2}{c|}{ ANEEL 336 July 2002 to Date } \\
\cline { 2 - 5 } & Demand $R \$ / k W$ & Consume R\$/kWh & Demand USD/kW & Consume USD/kWh \\
\hline A4 (13,8V Medium Volt.) & $\mathrm{R} \$ 7.720$ & $\mathrm{R} \$ 0.11312$ & USD 2.4469 & USD 0.0359 \\
\hline B1 (Residential Low Volt) & & $\mathrm{R} \$ 0.21949$ & & USD 0.0696 \\
\hline B3 (Comm. \& Ind. Low Volt.) & & $\mathrm{R} \$ 0.20527$ & & USD 0.0651 \\
\hline
\end{tabular}

Lactec power plant generated 730,495 kWh during period, 189,447 kWh under the first rate period (ANEEL regulation 226) and 541,048 kWh during second one (ANEEL regulation 336). The applicable rate for Lactec Data Center is the A4 $(13.8 \mathrm{~V})$, so the resulting electrical energy savings were:

Elec. Saving $=(\mathrm{kW}$ Demand $*$ Months * Demand Rate USD $/ \mathrm{kW})+(\mathrm{kWh}$ Generated * Consume Rate USD $/ \mathrm{kWh})$

Displaced kWh Rate $=$ Total Electrical Energy Cost $/ \mathrm{kWh}$ Generated

\begin{tabular}{|c|c|c|c|c|c|c|c|}
\hline Rate & kWh Generated & Months & $\begin{array}{c}\text { Demand } \\
\text { kW }\end{array}$ & \begin{tabular}{c}
\multicolumn{2}{c}{ Demand } \\
Rate USD \\
/ kW
\end{tabular} & $\begin{array}{l}\text { Consume } \\
\text { USD/kWh }\end{array}$ & $\begin{array}{c}\text { Total Cost } \\
\text { USD }\end{array}$ & $\begin{array}{c}\text { kWh Rate } \\
\text { USD }\end{array}$ \\
\hline A4 Aneel 226 & $189,446.60$ & 3 & 200 & 2.2060 & 0.0323 & 7,445.35 & 0.03930 \\
\hline A4 Aneel 336 & $541,048.70$ & 10 & 200 & 2.4469 & 0.0359 & $24,292.69$ & 0.04490 \\
\hline Total & $730,495.30$ & 13 & 200 & & & $31,738.04$ & 0.04345 \\
\hline
\end{tabular}

\section{6-Results:}

During this period the power plant cost vs. savings did not generate any net savings because of the utilization of natural gas to generate electrical and thermal energy. In fact, the result shows loses that reached USD 144,196.32 (gas HHV). At the same time the resulting power plant electrical energy cost was far from being competitive with the electrical rates available on the State of Parana. The results are described on the next chart.

Considering the application low demand, an analysis was also prepared estimating costs and savings under different demand cases to identify those where the power plant application into the Brazilian power market would generate a positive result. As shown on the next second chart, considering displaced electrical energy at $13.8 \mathrm{~V}$ rate (A4) the power plant does not generate any savings. Neither when considering the potential benefit of ANEEL regulation 21/2000 that states requirements for cogeneration devices, allowing benefits that reaches to a $50 \%$ discount on natural gas cost. Besides at a maximum demand and getting the benefits of ANEEL 21/2000, the power plant electric energy cost, can be competitive with Residential Low Volt Rate (B1) and Commercial \& Industrial Low Volt Rate (B3), but not with $13.8 \mathrm{~V}$ rate $(\mathrm{A} 4)$. 


\section{COST Vs. SAVINGS ANALYSIS}

Based on system effective demand for the period

\begin{tabular}{|c|c|c|c|c|c|c|c|c|c|c|}
\hline Case & $\begin{array}{l}\text { Elec. } \\
\text { Cap. } \\
\text { Factor }\end{array}$ & $\begin{array}{c}\text { Thermal } \\
\text { Util. }\end{array}$ & $\begin{array}{c}\text { Displaced } \\
\text { kWh }\end{array}$ & $\begin{array}{c}\text { Displaced } \\
\text { Gas } \\
\text { kBtu } \\
\end{array}$ & $\begin{array}{c}\text { Capital } \\
\text { Amortization } \\
\text { USD }\end{array}$ & $\begin{array}{c}\text { First Year } \\
\text { Maintenance } \\
\text { USD } \\
\end{array}$ & $\begin{array}{c}\text { Nat. Gas } \\
\text { Cost } \\
\text { USD } \\
\end{array}$ & $\begin{array}{l}\text { Nat. Gas } \\
\text { Savings } \\
\text { USD }\end{array}$ & \begin{tabular}{|c|} 
Electrical \\
Savings A4 \\
USD
\end{tabular} & $\begin{array}{c}\text { Net Savings } \\
\text { USD }\end{array}$ \\
\hline \multicolumn{11}{|c|}{ Lactec Fuel Cell Cost / Savings Analysis for the Period, based on effective demand } \\
\hline Nat. Gas LHV & $43.00 \%$ & $0.00 \%$ & $730,495.30$ & 0.00 & $93,117.99$ & $22,570.41$ & $60,245.96$ & 0.00 & $31,738.04$ & $-144,196.32$ \\
\hline Nat. Gas HHV & $43.00 \%$ & $0.00 \%$ & $730,495.30$ & 0.00 & $93,117.99$ & $22,570.41$ & $60,245.96$ & 0.00 & $31,738.04$ & $-144,196.32$ \\
\hline
\end{tabular}

\section{POWER PLANT ELECTRICAL ENERGY RATE vS. UTILITY GRID ELECTRICAL ENERGY RATES}

Based on system effective demand for the period

\begin{tabular}{|c|c|c|c|c|c|c|c|c|c|c|c|c|}
\hline Case & $\begin{array}{l}\text { Elec. } \\
\text { Cap. } \\
\text { Factor }\end{array}$ & $\begin{array}{c}\text { Thermal } \\
\text { Util. }\end{array}$ & $\begin{array}{c}\text { Displaced } \\
\text { kWh }\end{array}$ & $\begin{array}{c}\text { Displaced } \\
\text { Gas } \\
\text { kBtu }\end{array}$ & $\begin{array}{c}\text { Capital } \\
\text { Amortization } \\
\text { USD }\end{array}$ & $\begin{array}{c}\text { First Year } \\
\text { Maintenance } \\
\text { USD }\end{array}$ & $\begin{array}{l}\text { Nat. Gas } \\
\text { Cost } \\
\text { USD }\end{array}$ & $\begin{array}{l}\text { Nat. Gas } \\
\text { Savings } \\
\text { USD }\end{array}$ & $\begin{array}{c}\text { kWh } \\
\text { Generated } \\
\text { Cost USD }\end{array}$ & $\begin{array}{l}\text { A4 }(13,8 \mathrm{~V} \\
\text { Medium } \\
\text { Volt.) }\end{array}$ & $\begin{array}{c}\text { B1 } \\
\text { (Residential } \\
\text { Low Volt) }\end{array}$ & $\begin{array}{c}\text { B3 } \\
\begin{array}{c}\text { (Comm. \& Ind. } \\
\text { Low Volt.) }\end{array} \\
\end{array}$ \\
\hline \multicolumn{13}{|c|}{ Lactec Fuel Cell kWh Generated Cost for the Period, based on effective demand, compared with utility grid available rate cost for the same period. } \\
\hline Nat. Gas LHV & $43.00 \%$ & $0.00 \%$ & $730,495.30$ & 0.00 & $93,117.99$ & $22,570.41$ & $60,245.96$ & 0.00 & 0.24084 & 0.04345 & 0.06779 & 0.06340 \\
\hline Nat. Gas HHV & $43.00 \%$ & $0.00 \%$ & $730,495.30$ & 0.00 & $93,117.99$ & $22,570.41$ & $60,245.96$ & 0.00 & 0.24084 & 0.04345 & 0.06779 & 0.06340 \\
\hline
\end{tabular}


COST Vs. SAVINGS ANALYSIS

Estimations according to different demand percentages.

\begin{tabular}{|c|c|c|c|c|c|c|c|c|c|c|}
\hline Case & $\begin{array}{l}\text { Elec. Cap. } \\
\text { Factor }\end{array}$ & $\begin{array}{c}\text { Thermal } \\
\text { Util. }\end{array}$ & Displaced kWh & $\begin{array}{c}\text { Displaced } \\
\text { Gas } \\
\text { kBtu }\end{array}$ & $\begin{array}{c}\text { Capital } \\
\text { Amortization } \\
\text { USD }\end{array}$ & $\begin{array}{l}\text { First Year } \\
\text { Maintenance } \\
\text { USD }\end{array}$ & $\begin{array}{c}\text { Nat. Gas } \\
\text { Cost } \\
\text { USD }\end{array}$ & $\begin{array}{l}\text { Nat. Gas } \\
\text { Savings } \\
\text { USD }\end{array}$ & $\begin{array}{c}\text { Electrical } \\
\text { Savings A4 } \\
\text { USD }\end{array}$ & $\begin{array}{c}\text { Net Savings } \\
\text { USD }\end{array}$ \\
\hline \multicolumn{11}{|c|}{ Lactec Fuel Cell Cost / Savings Analysis considering a typical Demand } \\
\hline Nat. Gas LHV & $90.00 \%$ & $40.00 \%$ & $1,540,440.00$ & $3,667,826.96$ & $93,117.99$ & $22,570.41$ & $96,324.16$ & $31,840.79$ & $60,244.87$ & $-119,926.90$ \\
\hline Nat. Gas HHV & $90.00 \%$ & $40.00 \%$ & $1,540,440.00$ & $3,667,826.96$ & $93,117.99$ & $22,570.41$ & $96,324.16$ & $29,308.00$ & $60,244.87$ & $-122,459.69$ \\
\hline \multicolumn{11}{|c|}{ Lactec Fuel Cell Cost / Savings Analysis considering a $100 \%$ Demand } \\
\hline Nat. Gas LHV & $100.00 \%$ & $100.00 \%$ & $1,711,600.00$ & $9,169,567.39$ & $93,117.99$ & $22,570.41$ & $125,932.69$ & $75,372.71$ & $65,862.49$ & $-100,385.89$ \\
\hline Nat. Gas HHV & $100.00 \%$ & $100.00 \%$ & $1,711,600.00$ & $9,169,567.39$ & $93,117.99$ & $22,570.41$ & $125,932.69$ & $70,052.59$ & $65,862.49$ & $-105,706.01$ \\
\hline \multicolumn{11}{|c|}{ Lactec Fuel Cell Cost / Savings Analysis considering a $100 \%$ Demand and getting a $50 \%$ Benefit on Natural Gas cost as a result of applying to ANEEL $21 / 2000$} \\
\hline Nat. Gas LHV & $100.00 \%$ & $100.00 \%$ & $1,711,600.00$ & $9,169,567.39$ & $93,117.99$ & $22,570.41$ & $62,966.35$ & $75,372.71$ & $65,862.49$ & $-37,419.54$ \\
\hline Nat. Gas HHV & $100.00 \%$ & $100.00 \%$ & $1,711,600.00$ & $9,169,567.39$ & $93,117.99$ & $22,570.41$ & $62,966.35$ & $70,052.59$ & $65,862.49$ & $-42,739.67$ \\
\hline
\end{tabular}

POWER PLANT ELECTRICAL ENERGY RATE vs. UTILITY GRID ELECTRICAL ENERGY RATES

Estimations according to different demand percentages.

\begin{tabular}{|c|c|c|c|c|c|c|c|c|c|c|c|c|}
\hline Case & $\begin{array}{l}\text { Elec. } \\
\text { Cap. } \\
\text { Factor }\end{array}$ & $\begin{array}{c}\text { Thermal } \\
\text { Util. }\end{array}$ & $\begin{array}{l}\text { Displaced } \\
\text { kWh }\end{array}$ & $\begin{array}{c}\text { Displaced } \\
\text { Gas } \\
\text { kBtu } \\
\end{array}$ & $\begin{array}{c}\text { Capital } \\
\text { Amortization } \\
\text { USD }\end{array}$ & $\begin{array}{c}\text { First Year } \\
\text { Maintenance } \\
\text { USD } \\
\end{array}$ & $\begin{array}{c}\text { Nat. Gas } \\
\text { Cost } \\
\text { USD } \\
\end{array}$ & $\begin{array}{c}\text { Nat. Gas } \\
\text { Savings } \\
\text { USD }\end{array}$ & $\begin{array}{c}\text { kWh } \\
\text { Generated } \\
\text { Cost USD } \\
\end{array}$ & $\begin{array}{l}\text { A4 }(13,8 \mathrm{~V} \\
\text { Medium } \\
\text { Volt.) }\end{array}$ & $\begin{array}{c}\text { B1 } \\
\begin{array}{c}\text { (Residential } \\
\text { Low Volt) }\end{array} \\
\end{array}$ & $\begin{array}{c}\text { B3 } \\
\begin{array}{c}\text { (Comm. \& Ind. } \\
\text { Low Volt.) }\end{array}\end{array}$ \\
\hline \multicolumn{13}{|c|}{ Lactec Fuel Cell kWh Generated Cost, considering a typical Demand, compared with available utility grid rate costs. } \\
\hline Nat. Gas LHV & $90.00 \%$ & $40.00 \%$ & $1,540,440.00$ & $3,667,826.96$ & $93,117.99$ & $22,570.41$ & $96,324.16$ & $31,840.79$ & 0.11696 & 0.03911 & 0.06805 & 0.06364 \\
\hline Nat. Gas HHV & $90.00 \%$ & $40.00 \%$ & $1,540,440.00$ & $3,667,826.96$ & $93,117.99$ & $22,570.41$ & $96,324.16$ & $29,308.00$ & 0.11861 & 0.03911 & 0.06805 & 0.06364 \\
\hline \multicolumn{13}{|c|}{ Lactec Fuel Cell kWh Generated Cost, considering a 100\% Demand, compared with available utility grid rate costs. } \\
\hline Nat. Gas LHV & $100.00 \%$ & $100.00 \%$ & $1,711,600.00$ & $9,169,567.39$ & $93,117.99$ & $22,570.41$ & $125,932.69$ & $75,372.71$ & 0.09713 & 0.03848 & 0.06805 & 0.06364 \\
\hline Nat. Gas HHV & $100.00 \%$ & $100.00 \%$ & $1,711,600.00$ & $9,169,567.39$ & $93,117.99$ & $22,570.41$ & $125,932.69$ & $70,052.59$ & 0.10024 & 0.03848 & 0.06805 & 0.06364 \\
\hline \multicolumn{13}{|c|}{$\begin{array}{l}\text { Lactec Fuel Cell kWh Generated Cost, considering a } 100 \% \text { Demand and getting a } 50 \% \text { Benefit on Natural Gas cost as a result of applying } \\
\text { to ANEEL } 21 / 2000 \text {, compared with utility grid available rate costs. }\end{array}$} \\
\hline Nat. Gas LHV & $100.00 \%$ & $100.00 \%$ & $1,711,600.00$ & $9,169,567.39$ & $93,117.99$ & $22,570.41$ & $62,966.35$ & $75,372.71$ & 0.06034 & 0.03848 & 0.06805 & 0.06364 \\
\hline Nat. Gas HHV & $100.00 \%$ & $100.00 \%$ & $1,711,600.00$ & $9,169,567.39$ & $93,117.99$ & $22,570.41$ & $62,966.35$ & $70,052.59$ & 0.06345 & 0.03848 & 0.06805 & 0.06364 \\
\hline
\end{tabular}


The combination of many factors affected the economical results. These factors can be summarized under the following categories:

Related to the Application:

- Effective installation cost was 70\% more expensive than forecasted cost.

- Low Electrical Capacity Utilization (43\%)

- Limited availability of Thermal Loads $(0 \%)$

Related to the Brazilian Energy Market:

- The cost difference between natural gas and electrical energy rate, demands a high efficiency for the electrical generation from the gas utilization in order to turn it equal to conventional electrical market rates. As shown, project displaced electricity rate was USD $0.04345 \mathrm{kWh}$; the natural gas rate was USD $0.023528 \mathrm{kWh}$ just in order to equalize both rates the power plant should reach to $54 \%$ efficiency and that is without considering any amortization or maintenance costs factors.

The small difference does not provide the necessary savings to support maintenance cost and amortization rate, being the result that the electrical generation from the power plant is more expensive than conventional electrical rates.

Related to the Power Plant

- The high cost of acquisition creates a high amortization rate per year.

\section{Conclusions:}

According to the evaluation of the results we conclude that the power plant has demonstrated to be a reliable system that complies with premium power supply requirements.

In terms of efficiency, the power plant has demonstrated to perform better than other technologies when referring to electric energy generation. The power plant considerable thermal output represents an additional advantage and its utilization on applications with available thermal loads not only improves the system efficiency but also contributes to the economical viability of the project results.

It was also demonstrated that the use of fuel cell technology greatly contributes to the improvement of the local environment by not releasing harmful emissions.

At this time the commercialization efforts to promote fuel cell technology presents a barrier due to the expensive cost of the equipment compared with traditional sources of power generation, becoming competitive when critical factors are considered as a measure of success.

The achievement of this project has without a doubt contributed to exposing fuel cell technology to a new continent, providing a source of regional evaluation, technical education and expertise and a path to commercial opportunities that will be applicable on future projects.

We can conclude that fuel cell technology provides a reliable option for the maturing concept of distributed generation as an important alternative for environmental clean power generation. 


\section{Statistics:}

Period Summary Statistics: April 13, 2002 through April 15, 2003.

Hours of Operation:

Total Electric Output:

Average Fuel Cell Output:

Total Heat Recovered:

Heat Recovery Rate:

Input Fuel:

$\begin{array}{clr}\text { 8558Hours } & \text { Electric Efficiency: } & 28.5 \% \\ \text { 730.50MWhrs } & \text { Thermal Efficiency: } & 0.0 \% \\ \text { 85.0kW } & \text { Total Efficiency: } & 28.5 \% \\ \text { 0.0MMBtu } & \text { Electric Capacity Factor: } & 42.51 \% \\ \text { OkBtu/Hr } & \text { Availability: } & 97.2 \% \\ 8,988,671 \text { Cubic Feet } & & \end{array}$

\begin{tabular}{|c|c|c|c|c|c|c|c|c|c|c|c|c|}
\hline MONTH & $\begin{array}{c}\text { Operating } \\
\text { Hours }\end{array}$ & $\begin{array}{c}\text { Calendar } \\
\text { Time }\end{array}$ & KWHRS & $\begin{array}{c}\text { Average } \\
\text { AC } \\
\text { Output } \\
\text { kW }\end{array}$ & $\begin{array}{l}\text { Nat. Gas } \\
\text { Consume } \\
\text { Cubic Feet }\end{array}$ & $\begin{array}{c}\text { Nat. Gas } \\
\text { Consume } \\
\text { Cubic } \\
\text { Feet/Hrs }\end{array}$ & $\begin{array}{c}\text { Nat. Gas } \\
\text { Consume } \\
\text { Cubic } \\
\text { Meter }\end{array}$ & $\begin{array}{c}\text { Nat. Gas } \\
\text { Consume } \\
\text { Cubic } \\
\text { Meter/Hrs }\end{array}$ & $\begin{array}{c}\text { Heat } \\
\text { Recovered } \\
\text { KBTUHRS }\end{array}$ & $\begin{array}{c}\% \\
\text { Availability }\end{array}$ & $\begin{array}{c}\text { Avg. } \\
\text { El. Eff. } \\
\text { Nat. } \\
\text { Gas } \\
\text { LHV }\end{array}$ & \begin{tabular}{|c|} 
Avg. \\
Therm. \\
Eff. \\
Nat. \\
Gas \\
LHV \\
\end{tabular} \\
\hline Apr-02 & 426 & 451 & $50,143.20$ & 115.1 & $568,817.1$ & $1,334.9$ & $16,107.1$ & 37.8 & 0.0 & $94.5 \%$ & $30.9 \%$ & $0.0 \%$ \\
\hline CTD & 426 & 451 & $50,143.20$ & 115.1 & $568,817.1$ & $1,334.9$ & $16,107.1$ & 37.8 & 0.0 & $94.5 \%$ & $30.9 \%$ & $0.0 \%$ \\
\hline May-02 & 742 & 742 & $115,314.10$ & 157.5 & $1,163,119.0$ & $1,567.9$ & $32,935.9$ & 44.4 & 0.0 & $100.0 \%$ & $34.8 \%$ & $0.0 \%$ \\
\hline CTD & 1169 & 1194 & $165,757.30$ & 138.8 & $1,734,731.1$ & $1,483.5$ & $49,122.1$ & 42.0 & 0.0 & $97.9 \%$ & $33.5 \%$ & $0.0 \%$ \\
\hline Jun-02 & 715 & 715 & $23,689.30$ & 33.2 & $573,597.0$ & 802.3 & $16,242.5$ & 22.7 & 0.0 & $100.0 \%$ & $14.5 \%$ & $0.0 \%$ \\
\hline CTD & 1889 & 1914 & $189,446.60$ & 103.1 & $2,311,217.1$ & $1,223.3$ & $65,446.4$ & 34.6 & 0.0 & $98.7 \%$ & $28.8 \%$ & $0.0 \%$ \\
\hline Jul-02 & 740 & 740 & $33,824.30$ & 44.7 & $633,158.0$ & 855.8 & $17,929.0$ & 24.2 & 0.0 & $100.0 \%$ & $18.8 \%$ & $0.0 \%$ \\
\hline CTD & 2634 & 2659 & $223,520.80$ & 88.1 & $2,948,895.1$ & $1,119.5$ & $83,503.4$ & 31.7 & 0.0 & $99.1 \%$ & $26.6 \%$ & $0.0 \%$ \\
\hline Aug-02 & 738 & 738 & $39,712.20$ & 63.0 & $647,305.0$ & 877.1 & $18,329.6$ & 24.8 & 0.0 & $100.0 \%$ & $21.5 \%$ & $0.0 \%$ \\
\hline CTD & 3377 & 3402 & $263,233.00$ & 84.4 & $3,599,087.1$ & $1,065.8$ & \begin{tabular}{|l|}
$101,914.8$ \\
\end{tabular} & 30.2 & 0.0 & $9.3 \%$ & $25.7 \%$ & $0.0 \%$ \\
\hline Sep-02 & 672 & 672 & $45,508.90$ & 95.4 & $691,000.0$ & $1,027.5$ & \begin{tabular}{|r|}
$19,566.9$ \\
\end{tabular} & 29.1 & 0.0 & $100.0 \%$ & $23.1 \%$ & $0.0 \%$ \\
\hline CTD & 4098 & 4122 & $309,525.10$ & 86.0 & $4,322,911.1$ & $1,055.0$ & $122,411.2$ & 29.9 & 0.0 & $99.4 \%$ & $25.1 \%$ & $0.0 \%$ \\
\hline Oct-02 & 321 & 354 & $38,688.90$ & 135.5 & $885,123.0$ & $2,757.2$ & \begin{tabular}{|r|}
$25,063.9$ \\
\end{tabular} & 78.1 & 0.0 & $90.6 \%$ & $15.3 \%$ & $0.0 \%$ \\
\hline CTD & 4424 & 4482 & $349,213.80$ & 90.3 & $5,217,478.1$ & $1,179.4$ & \begin{tabular}{|l|}
$147,742.5$ \\
\end{tabular} & 33.4 & 0.0 & $98.7 \%$ & $23.5 \%$ & $0.0 \%$ \\
\hline Nov-02 & 58 & 716 & $88,445.90$ & 126.7 & $833,425.0$ & $1,494.4$ & \begin{tabular}{|r|}
$23,600.0$ \\
\end{tabular} & 42.3 & 0.0 & $77.9 \%$ & $37.3 \%$ & $0.0 \%$ \\
\hline CTD & 5371 & 5587 & $483,849.80$ & 97.5 & $6,060,331.1$ & $1,128.3$ & \begin{tabular}{|l|}
$171,609.5$ \\
\end{tabular} & 31.9 & 0.0 & $96.1 \%$ & $28.0 \%$ & $0.0 \%$ \\
\hline Dec-02 & 739 & 739 & $72,096.80$ & 93.6 & $678,281.0$ & 918.0 & \begin{tabular}{|r|}
$19,206.8$ \\
\end{tabular} & 26.0 & 0.0 & $100.0 \%$ & $37.3 \%$ & $0.0 \%$ \\
\hline CTD & 6115 & 6331 & $556,446.50$ & 97.0 & $6,743,168.1$ & $1,102.7$ & \begin{tabular}{|l|}
$190,945.3$ \\
\end{tabular} & 31.2 & 0.0 & $96.6 \%$ & $29.0 \%$ & $0.0 \%$ \\
\hline Jan-03 & 739 & 739 & $36,937.30$ & 50.0 & $680,549.0$ & 921.1 & $19,271.0$ & 26.1 & 0.0 & $100.0 \%$ & $19.1 \%$ & $0.0 \%$ \\
\hline CTD & 6859 & 7075 & $593,633.90$ & 89.5 & $7,428,326.1$ & $1,083.0$ & \begin{tabular}{|l|}
$210,346.8$ \\
\end{tabular} & 30.7 & 0.0 & $96.9 \%$ & $28.1 \%$ & $0.0 \%$ \\
\hline Feb-03 & 640 & 666 & $32,456.20$ & 42.9 & $588,405.0$ & 920.0 & \begin{tabular}{|r|}
$16,661.8$ \\
\end{tabular} & 26.1 & 0.0 & $96.0 \%$ & $19.4 \%$ & $0.0 \%$ \\
\hline CTD & 7503 & 7746 & $626,340.20$ & 81.4 & $8,021,362.1$ & $1,069.0$ & \begin{tabular}{|l|}
$227,139.7$ \\
\end{tabular} & 30.3 & 0.0 & $96.9 \%$ & $27.4 \%$ & $0.0 \%$ \\
\hline Mar-03 & 739 & 740 & $72,830.50$ & 97.7 & $676,874.0$ & 916.1 & \begin{tabular}{|r|}
$19,166.9$ \\
\end{tabular} & 25.9 & 0.0 & $99.9 \%$ & $37.8 \%$ & $0.0 \%$ \\
\hline CTD & 8247 & 8491 & $699,670.60$ & 83.7 & $8,702,823.1$ & $1,055.2$ & $246,436.5$ & 29.9 & 0.0 & $97.1 \%$ & $28.2 \%$ & $0.0 \%$ \\
\hline Apr-03 & 306 & 306 & $30,324.90$ & 99.5 & $281,235.0$ & 919.2 & \begin{tabular}{|r|}
$7,963.7$ \\
\end{tabular} & 26.0 & 0.0 & $100.0 \%$ & $37.9 \%$ & $0.0 \%$ \\
\hline CTD & 8558 & 8802 & $730,495.30$ & 85.0 & $8,988,671.1$ & $1,050.3$ & $254,530.9$ & 29.7 & 0.0 & $97.2 \%$ & $28.5 \%$ & $0.0 \%$ \\
\hline
\end{tabular}




\section{Information Source}

i. Cogeneration Case Studies of the DoD Fuel Cell Demonstration Program

(Presented at the IQPC F-CELL Stationary Conference London, UK - February 29,2000)

ii. Experience with the DoD Fleet of 30 Fuel Cell Generators

(Presented at the 2001 International Gas Research Conference-IGRC 2001- November 5-8, 2001)

iii. Gas and Electricity Rates on South America (Protecnia IAPG Magazine, N ${ }^{\circ} 4$ August, 2002)

iv. UTC Fuel Cell (www.utcfuelcells.com)

v. DoD Fuel Cell ERDC-CERL (www.dodfuelcell.com)

vi. Companhia Paranaense de Energia - COPEL - (www.copel.com)

vii. Companhia Paranaense de Gas - COMPAGAS - (www.compagas.com)

viii. IAPG Argentine Institute of Petroleum and Gas (www.iapg.org.ar) 


\section{Photo Gallery}

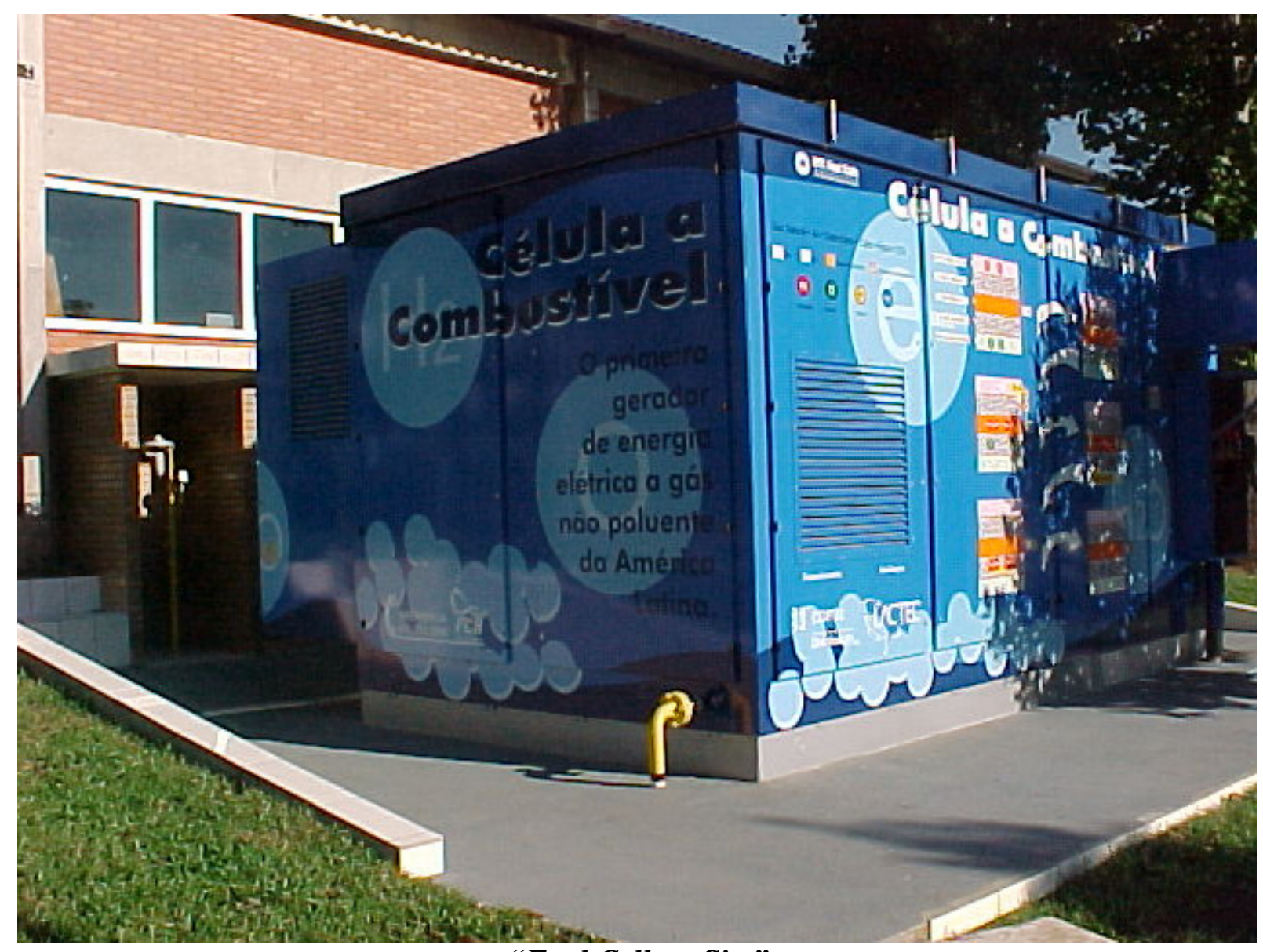

"Fuel Cell on Site" 


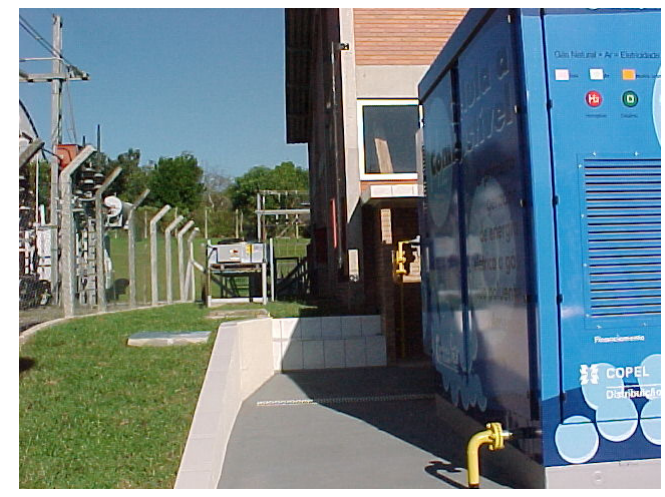

Fuel Cell and Cooling Module

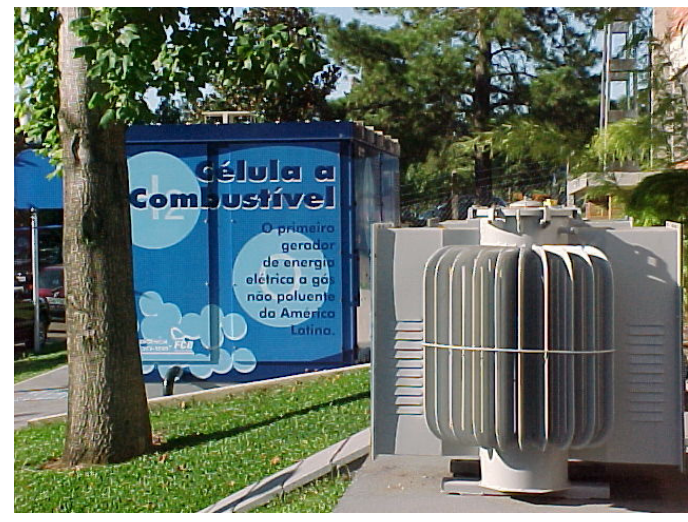

Fuel Cell On Site

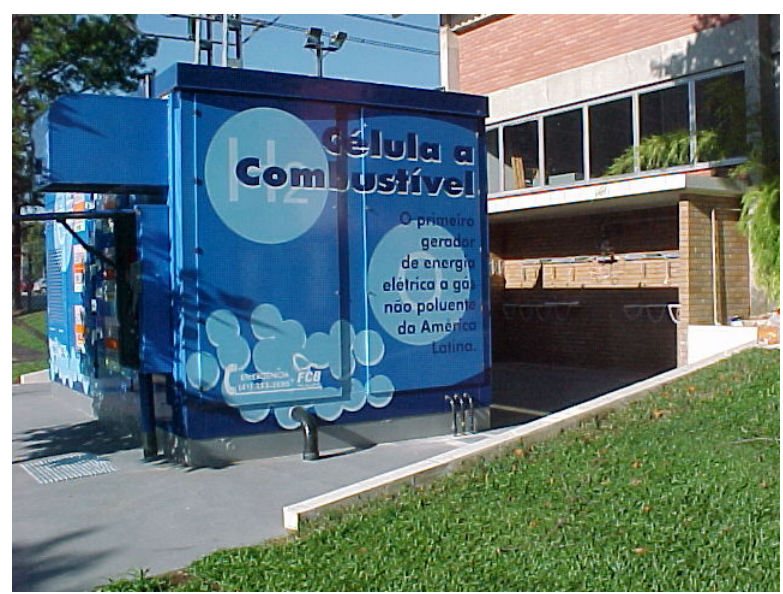

Fuel Cell On Site

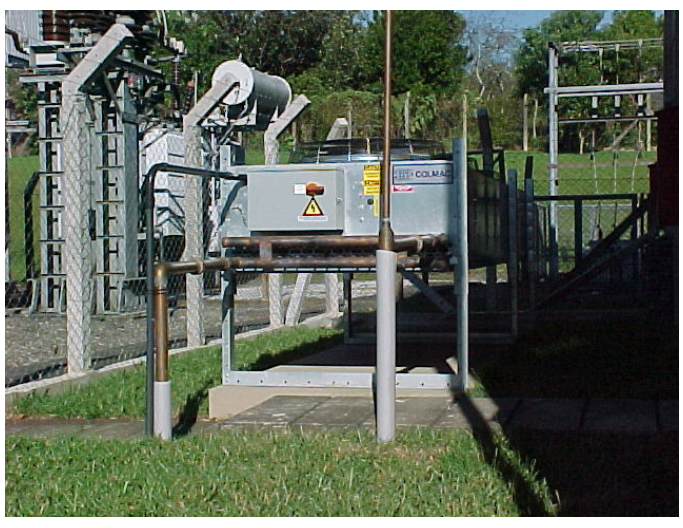

Cooling Module 


\section{Contact \& Addresses}

Eduardo Browne

Director

SiecoUS@aol.com

SIECO S.A.

Av. Juan de Garay 437

(C1153ABC) Buenos Aires, Argentina

Tel.: (5411) 4300-9999

Fax: (5411) 4300-9998

www.sieco.com.ar

SIECO USA Representative Office

33 Cherry Lane

Airmont, New York 10952

Tel.: 845-369-0382 